\title{
A CROSS-SECTIONAL ANALYSIS OF BRAZIL'S WATER POLLUTION CONTROL REGULATION: SUGGESTIONS BASED ON THE USA REGULATION
}

\author{
LILIAN BECHARA ELABRAS VEIGA \& ALESSANDRA MAGRINI \\ Energy Planning Program, Rio de Janeiro Federal University, Brazil.
}

\begin{abstract}
In Brazil, Law 9,433, enacted in 1997, established the National Water Resources Policy and created the National Water Resources Management System, introducing a new integrated approach to environmental management policies. This law defined the hydrographic basin as the unit of planning, considering multiple water uses, introducing many changes at the institutional and policy instruments levels. Fifteen years after the enactment of the above law, improvements still need to be done. Evidence of this is the process of revising the rules on pollutant discharge on water bodies. Despite the latest changes, there still exist improvements that could be considered. This paper aims to contribute to this effort, by comparing the Brazilian water pollution control model with the American model, which can provide valuable insights in terms of defining pollutant discharge limits based on industrial typologies, and especially for having pollution control instruments such as the total maximum daily load and the water quality trading policy. Finally, based on the US model, this paper makes suggestions that could be incorporated in Brazil to make water pollution control more effective.

Keywords: Brazil, effluent discharge, pollution control, total maximum daily load, United States, water quality, water quality index.
\end{abstract}

\section{INTRODUCTION}

The evolution of Brazil's institutional model on water resources management advanced greatly in 1997 with the enactment of Law 9,433, which established the National Water Resources Policy (NWRP) and created the National Water Resources Management System (NWRMS). The law introduced important changes at the institutional and policy levels [1]. It defined the river basin as the territorial unit for water resources planning, breaking theoretically with the political-administrative division of the country into 27 states. The law also defined water as a public asset, scarce and endowed with economic value.

From the policy instrument perspective, the law defined five management instruments and worked toward the integration of these instruments with the other instruments defined by the country's environmental legislation [2]. As defined by the law, these instruments are [2, 3]:

- River basin plans, at three levels - federal, state and river basin: These define and identify management actions, plans, projects, works and investments that have priority for the watershed.

- Classification of water bodies according to their designated uses: This system establishes water quality targets to be met in a determined time frame. The water use classes are established by infra-legal regulations, particularly CONAMA Resolution 357/2005.

- Water permits: These permits allow the use of water for a determined period, seeking to assure water use within quantitative and qualitative limits. The permits are granted according to the priorities defined in the water resource plan, to preserve multiple water uses and to maintain the classification of the particular water body.

- Water fees: The purpose of these, besides raising revenue, is to send economic signals to society of the need for rational and sustainable water use, based on the principle that water is a common economic good. The money raised is earmarked for water management and conservation. 
- Water resources information system: As the name suggests, this system gathers data on water resources, shedding light on their status and serving for studies of improvements.

At the institutional level, Law 9,433/1997 established a new organizational framework, the NWRMS, which involves shared ways of managing water [1]. The system is actually composed of the National Water Agency (ANA), the National Water Resources Board, state and Federal District water resources boards, river basin committees, and river basin agencies. The ANA is responsible for the implementation of the National Water Policy instruments. The river basin committees are the 'center of gravity' of the system, as these committees are the venue for discussing use conflicts, always seeking participatory and decentralized management of water resources through the practice of continuous negotiation among the stakeholders involved [4].

Among the above five management instruments, the classification of water bodies according to their designated uses aims to establish water quality targets and the time frames for their achievement. The categories and environmental guidelines for classifying surface water bodies were defined in subsequent regulations, issued by means of CONAMA Resolution 357/2005, which also established the conditions and standards for discharge of effluents [2]. However, these standards for discharge failed to consider the various types of discharging industries [2]. Because of these failings, various criticisms were made, prompting CONAMA to issue Resolution 430 in 2011. However, this new resolution still leaves much to be improved. The conditions and standards for effluent discharge still ignore the types of polluting activities. Furthermore, there is still little articulation of this resolution with the other instruments set forth in Law 9,433/1997. An important contribution to this process would be the inclusion of instruments that have been established in other countries, especially the United States, which has an advanced model of water pollution control.

Thus, the objective of this paper is to assess and compare the Brazilian and American pollution control models, which can provide valuable insights in terms of defining pollutant discharge limits based on industrial typologies, and especially for having pollution control instruments such as the total maximum daily load (TMDL) that integrates water quality and pollutant discharge on water bodies, allowing quarter quality standards to be met and the water quality trading policy (WQT), that enables the adoption of market-based approaches and the use of economic incentives for improving water quality and consequently reducing pollutant loads.

In light of the American model, this paper presents some suggestions that could be incorporated in Brazil to make management of water pollution more effective. The paper is divided as follows. Section 2 presents an overview of Brazilian water resources and water pollution control regulations (CONAMA Resolution 357/2005 and Resolution 430/2011). Section 3 presents the United States water pollution control law - the Clean Water Act - and the instruments set by the Act to address and manage the pollution in American rivers and streams. Section 4 briefly compares the Brazilian and the American water pollution control models in terms of regulations and instruments. Finally, the last section presents in light of the American model, some proposals that could be incorporated in Brazil to make water pollution control more integrated and effective.

\section{WATER RESOURCES IN BRAZIL}

\subsection{An overview}

Brazil's $8,514,876 \mathrm{~km}^{2}$ of territory and over 190,000,000 [5] people (2010 census) make it the fifth largest country in the world in landmass and population. The country's continental dimensions, contrasting climates, population distribution, and varied economic and social developments, among 
Table 1: Water resource distribution in Brazil.

\begin{tabular}{|c|c|c|c|c|}
\hline Geographic regions & Brazilian states & $\begin{array}{c}\text { Area } \\
\left(\text { million } \mathrm{km}^{2}\right)\end{array}$ & $\begin{array}{c}\text { Population } \\
\text { (million people) }\end{array}$ & $\begin{array}{c}\text { Water } \\
\text { availability }(\%)\end{array}$ \\
\hline North & $\begin{array}{l}\text { Acre, Amazonas, } \\
\text { Roraima, Rondônia, } \\
\text { Pará, Amapá e Tocantins }\end{array}$ & 3.8 & 14 & 68 \\
\hline Northeast & $\begin{array}{l}\text { Maranhão, Piauí, Ceará, } \\
\text { Rio Grande do Norte, } \\
\text { Paraíba, Pernambuco, } \\
\text { Alagoas, Sergipe e Bahia }\end{array}$ & 1.5 & 50 & 3 \\
\hline Midwest & $\begin{array}{l}\text { Goiás, Mato Grosso, } \\
\text { Mato Grosso do Sul and } \\
\text { the Federal District }\end{array}$ & 1.6 & 12 & 16 \\
\hline Southeast & $\begin{array}{l}\text { Minas Gerais, Espírito } \\
\text { Santo, Rio de Janeiro } \\
\text { and São Paulo. }\end{array}$ & 0.93 & 77 & 11 \\
\hline South & $\begin{array}{l}\text { Paraná, Santa Catarina } \\
\text { and Rio Grande do Sul }\end{array}$ & 0.58 & 26 & 7 \\
\hline
\end{tabular}

Source: Author, based on Refs. [5] and [6].

other factors, result in wide differences between its geographical regions. Brazil has a privileged position as regards water resources when compared with most countries. It is estimated that about $12 \%$ of the world's surface water resources are located in Brazil [6]. However, despite this abundance, Brazil's water is unevenly distributed among its five official geographic regions: $68 \%$ of the fresh water available in Brazil is located in the northern region, where only $7 \%$ of the country population lives. Only $32 \%$ of Brazilian water resources, therefore, are available to $93 \%$ of the country's people. This uneven distribution of water resources is shown in Table 1.

As Table 1 shows, the most dramatic departure from abundance can be found in the Northeast region, which includes most of the country's semi-arid region. Accounting for $18 \%$ of Brazil's territory and about $28 \%$ of its population, the Northeast region has only $3 \%$ of the country's water resources and is subject to recurrent, severe droughts, crop failures, and food shortages [6]. With $73 \%$ of the country's population, $11 \%$ of its territory, and about $7 \%$ of its water resources, the Southeast is the heart of Brazil's industrial economy and also has the highest agricultural production [6]. As the Brazilian National Water Agency (ANA) [6] explains, for a long time, the notion of quantitative abundance supported a culture of water wastefulness and the postponement of investments necessary for more efficient use and protection of water resources.

\subsection{Water pollution control regulation in Brazil}

In Brazil, CONAMA Resolution 357/2005 sets the guidelines for classifying water bodies according to their main uses, aiming to establish mandatory water quality targets [2]. This resolution also established the conditions and standards for discharging effluents into the water bodies (chapter IV). The classification of water bodies is the result of a planning process that establishes the quality level 
to be attained and/or maintained in a river basin, considering its main uses and restrictions. The permits for water catchment and discharge of wastewater, including treatment requirements, are granted by the ANA according to the classification of the water bodies and the water quality standards (WQS) needed to attain and/or maintain this classification. These in turn are set by CONAMA Resolution 357/2005. According to this resolution, 13 water classes are established: five for freshwater, four for brackish water, and four for saline water. Each one of these classes was defined according to the water quality required for the water body to comply with its designated use [2]. The resolution also defines WQS to be achieved and/or maintained in each water body segment.

Regarding effluent discharges in water bodies, in 2011 CONAMA Resolution 430/2011 repealed chapter IV (effluent discharge conditions and standards) of CONAMA Resolution 357/2005. In the same way as Resolution 357/2005, Resolution 430/2011 establishes fixed limits for pollutant discharges, thus making no distinction between these discharges according to the related polluting activity or industrial type or control technology. This inflexible control system has attracted a good deal of criticism, particularly from the industrial sector. According to the later resolution, the effluent from any pollution source may only be discharged directly or indirectly into a water body after being appropriately treated, always considering the conditions and the discharge limits set in the resolution. The resolution also forbids the discharge of any effluent without compliance with the conditions and limits established. These conditions and limits demonstrate a rigid control system, where they do not vary either by type of industrial activity and control technology. In addition, no instrument aiming to integrate effluent discharges, water body classification, and WQS was established.

\subsection{Water quality in Brazil}

In Brazil, the increasing urbanization has caused substantial deterioration of the country's water quality [6]. In parallel with this reduction in quality, water demand is growing in proportion to population, imposing the need to bring water from more distant sources to large urban centers, often in other basins. Compounding these problems is the inability of government to keep up with the need for treatment of household sewage, industrial wastewater, and agricultural runoff, all of which are highly polluting in varying ways $[6,7]$.

Water quality monitoring is done by the ANA as well as by states entities. Because of the need to establish a sustainable balance between economic development and population growth on the one hand and water quality and quantity on the other, the ANA established a program for qualitativequantitative water monitoring, through a network of 1,340 sampling points spread throughout the country [7]. At state level, there are currently about 2,400 additional monitoring points. Together these federal and state monitoring points have a density of 0.26 per $1,000 \mathrm{~km}^{2}$ [7]. However, according to the ANA 2011 Technical Report [7], only 17 out of the 27 Brazilian states have been reporting their monitoring data to the ANA.

The ANA also adopts a water quality index (WQI), based on the need to synthesize the information on various physicochemical parameters, with the aim of informing the public and guiding water quality planning and management actions. This index encompasses nine parameters: dissolved oxygen, fecal Coliform, hydrogen potential ( $\mathrm{pH}$ ), biochemical oxygen demand (BOD5,20), temperature, total nitrogen, total phosphorus, turbidity, and total residue [7]. The WQI reflects river basin and stream contamination as a result of urban and industrial effluent discharges.

Nevertheless, the WQI has some limitations, since it does not include several important parameters, such as toxic substances (e.g. heavy metals, pesticides, and organic compounds), pathogenic protozoa and substances that interfere with the organoleptic properties of the water [7]. Also, there are no standardized procedures in Brazil for collection and preservation of water samples. As a 


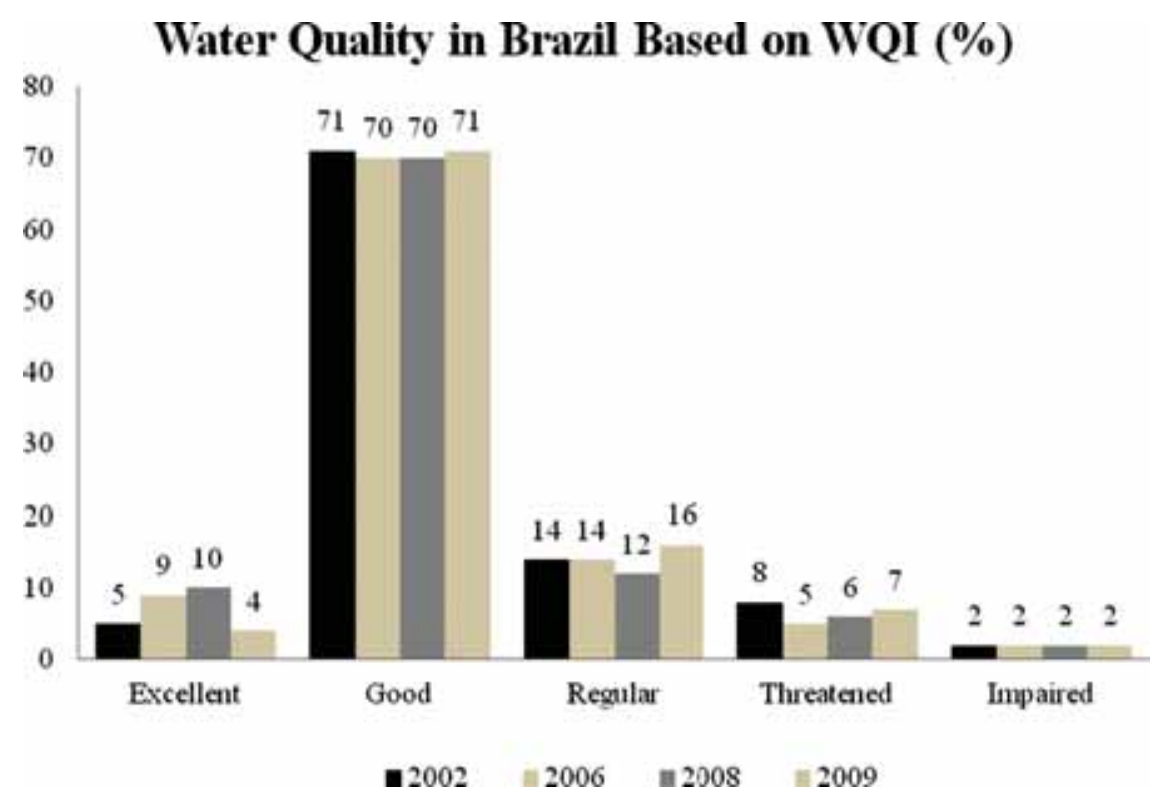

Figure 1: Water quality in sampled rivers and streams in 2002, 2006, 2008, and 2009. Source: Authors, based on Refs. [6,7].

consequence, two samples taken from a single segment of a river can present different results if analyzed by different institutions [7].

Figure 1 presents, based on the data provided by the ANA 2009 and 2011 Reports, the WQI results for the years 2002, 2006, 2008, and 2009. The numbers of sites monitored were 859 in 2002, 1,173 in $2006,1,812$, in 2008 , and 1,747 in 2009 , both at the federal and state level. Therefore, changes in class percentage do not mean trends in water quality improvement or deterioration, since the number of sites monitored is very different.

Figure 1 reveals that for the periods considered, the water quality distribution remained stable, keeping almost the same values, with the exception of the 'excellent' class, which first improved from $5 \%$ to $9 \%$ and then worsened from $10 \%$ to $4 \%$. As reported by the ANA, the probable sources of impairment can be attributed to the absence of appropriate sewage discharge systems in the majority of Brazilian municipalities, toxic substance discharges by industries, agricultural runoff, urban-related runoff, and other diffuse sources [7]. Unsurprisingly, the water bodies that showed WQI in the threatened and impaired classes are located close to the country's major metropolitan areas (São Paulo, Curitiba, Belo Horizonte, Porto Alegre, Rio de Janeiro, and Salvador) and medium-sized cities (Campinas in São Paulo state and Juiz de Fora in Minas Gerais). Usually improvements in WQI are related to investments in sanitation, industrial pollution control, and/or management of effluent discharges into reservoirs.

\section{WATER RESOURCES IN THE UNITED STATES}

\subsection{The American pollution control model}

In the United States, the states have relative autonomy in relation to the federal government [8]. The country has a system of agencies that have their own statutes approved by Congress. These laws define 
the agencies' objectives and areas of action. The regulations they issue have force of federal law throughout the country [8]. More specifically, the US Environmental Protection Agency (EPA), created in 1970, is entrusted with protecting human health and the environment: air, water, and soil [8].

The main law concerned with water resource management and pollution control is the Water Pollution Control Act or Clean Water Act (CWA). Enacted in 1948, the CWA has undergone several revisions. The CWA's last major amendment occurred in 1987, which established a program for controlling toxic pollutant discharges and a program requiring states to develop and implement measures to control nonpoint sources of pollution [9]. Before the 1987 amendment, the CWA only covered the control of individual pollutant sources. But the EPA along with the state authorities saw the need for greater control of nonpoint sources, responsible for over $60 \%$ of the pollution of the country's water bodies [10].

The CWA is guided by a policy of federal-state partnership, where the federal government establishes the agenda and limits while the states are tasked with implementing and overseeing enforcement of the determinations of the CWA [10]. The EPA is responsible for administering the programs and issuing the regulations and guidelines necessary to comply with the CWA. The CWA provides WQS for water bodies [11, 12]. According to the US-EPA [11, 12], it is up to each state or territory to implement and establish these standards, which consist of the designated uses for the particular water body, the quality criteria, and the anti-degradation policy $[11,12]$. These standards must be submitted to the EPA for approval and take effect when the agency declares them in conformity with the CWA.

Under the CWA, the effluent limits are defined for categories and classes of point sources $[9,13]$. Even though the CWA does not say whether effluent limits should be set on a facility-by-facility or industry-by-industry basis, the EPA sets industry-wide guidelines for effluent limits and technological standards for more than 50 major categories of industrial facilities [13]. These guidelines (CFR, Title 40, items 401 to 470) contain the limits on release of pollutants by categories of industrial facilities, whose technological standards are drafted based on the level of reduction that can be attained by each category of industry, through the use of specific technologies defined by the EPA (CWA Best Practicable Technology - BPT or Best Available Technology - BAT) [13].

In establishing these guidelines, the EPA considers two factors: (i) the performance of the best pollution control technologies or prevention practices that are available for a particular type of industry; and (ii) the economic probability of obtaining that technology, considering costs, benefits, and the value of managing to reduce pollutant discharges [13]. As Salzman and Thompson [10] explain: 'sources are free to meet the effluent limitation in whatever manner they wish, however they usually adopt the technology suggested by the EPA to set the limitation in the NPDES because they know that the technology will allow them to meet the effluent limitation'. Regarding new point sources, under the CWA they must meet effluent standards that reflect the greatest degree of reduction the EPA determines to be achievable through 'application of the best available control technology (BACT) process, operating methods including, where applicable, a standard permitting no discharge of pollutants' $[14,15]$.

The CWA also establishes the National Pollutant Discharge Elimination System (NPDES), introduced in its first revision, in the CWA 1972 revision [14]. The NPDES regulates the discharge of pollutants into US waters. Under the CWA, the discharge of any pollutants from a point source is not allowed unless it is authorized by an NPDES permit [14]. Therefore, the NPDES is a permit of discharge, which must be obtained by point sources. In most cases, the NPDES permit is administered by authorized states. The EPA decides on an appropriate numerical effluent limit, based on its guidelines, considering if the pollution released by the source is toxic, conventional, or unconventional, and based on what a specific technology can accomplish. 


\subsection{Water quality in the United States}

To address pollution in American rivers and streams, the CWA establishes the TMDL [9]. Under the CWA, American states must identify lakes, rivers, and streams for which effluent discharge limits are not stringent enough to achieve established WQS, after the implementation of technology-based controls by dischargers [16]. For each water body for which these limits are not stringent enough, the states are required to set a TMDL of pollutants at a level that ensures that applicable WQS can be attained. According to Copeland [15], the TMDL is a pollution budget, a quantitative estimate of what it takes to achieve state water quality goals, setting the maximum amount of pollution a water body can receive without violating WQS, including a margin of safety. As Copeland [15] explains 'A TMDL is both a planning process for attaining water quality standards and a quantitative assessment of problems, pollution sources, and pollutant reductions needed to restore and protect a river, stream, or lake'. TMDLs address major pollution sources, including point sources such as municipal sewage or industrial plant discharges; nonpoint sources, such as runoff from roads, farm fields and forests; and naturally occurring sources, such as runoff from undisturbed lands.

The TMDL is enforced by the states and the EPA through revisions to existing permits, which include the pollutant limits and a schedule for compliance. The TMDL is only one element of state water quality management programs. Other activities include standard setting, monitoring, permit issuance, and enforcement. Copeland [15] explains that over the years most American states have lacked the resources to do TMDL analyses, which involve complex assessment to ascribe and quantify environmental effects for particular discharge sources. Even though being established in 1972, the EPA issued regulations requiring states every two years to list waters that do not attain WQS and establish TMDLs only in 1992 [9]. Figure 2 presents the number of TMDLs implemented by all American states from 1996 to 2012.

Figure 2 reveals a major increase in the number of TMDLs implemented during these 14 years. From 1999 to 2000, the number of TMDLs implemented increased 4.7 times. From 2007 to 2008, their number doubled. According to Copeland [15], environmentalists see the TMDL as an important

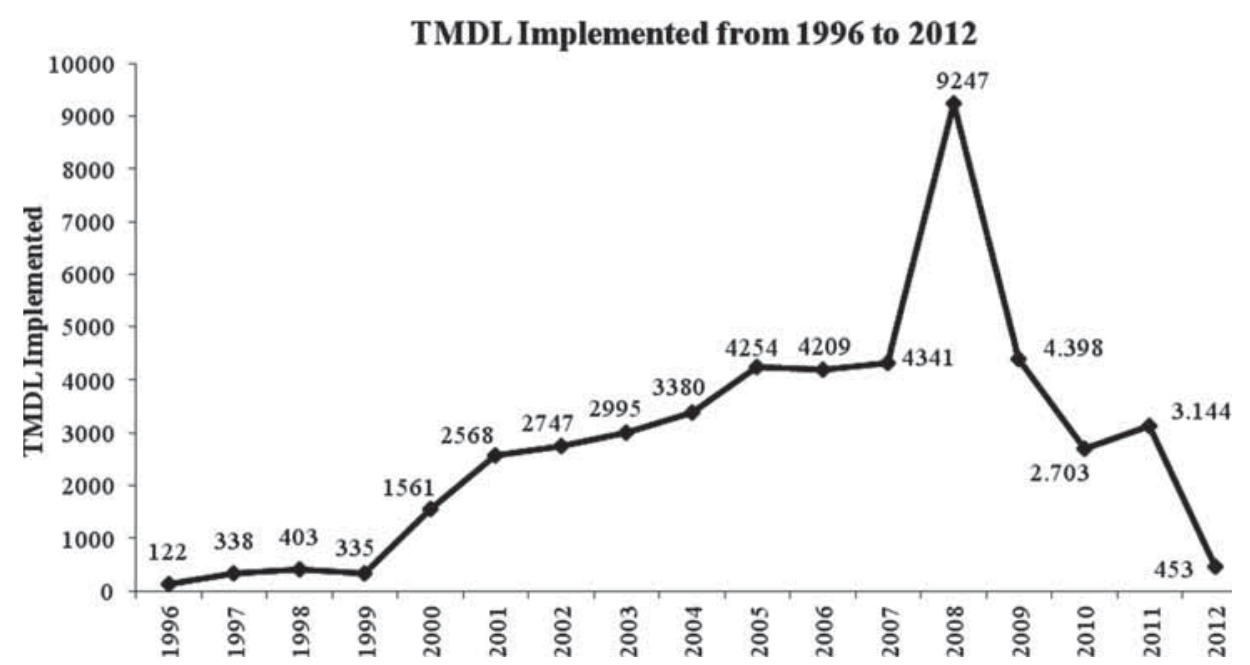

Figure 2: TMDLs implemented in the United States from 1996 to 2012. Source: Authors, based on http://www.epa.gov. 
tool to achieving the overall goals and objectives of the CWA and to pressure the EPA and states to address nonpoint and other sources of pollution, which are responsible for many water quality impairments nationwide.

In May 2008, the EPA provided the public access to a database called the Assessment Total Maximum Daily Load Tracking and Implementation System (ATTAINS). ATTAINS presents data on water quality for the country's water bodies (rivers, streams, lakes, and estuaries) based on technical reports submitted by the states to the EPA. Until then, in the same way as in Brazil, not all states had been reporting to the EPA (www.epa.gov, accessed August 30, 2011). Based on the data provided by ATTAINS, Fig. 3 presents the river and stream water quality data for the years 2002, 2004, 2006, 2008, and 2010. Only 20\% of American rivers and streams have been assessed, as not all states have reported their data to the EPA.

Figure 3 reveals that for the periods considered, water quality distribution demonstrated similar behavior, keeping almost the same values. As reported by Salzman and Thompson [10] the probable sources of impairment are agriculture, unknown sources, unspecified nonpoint sources, natural/ wildlife, sewage discharge, urban-related runoff, and atmospheric deposition.

The data presented in ATTAINS cannot be analyzed in a comparative way, as for each of the periods, different rivers have been monitored. Thus, the data presented in Fig. 3 should be used by EPA and the states to identify water bodies that are not meeting the WQS and to implement the tools necessary to control pollution and to restore the quality water, such as the TMDL.

In 2003, the EPA issued the WQT, enabling the adoption of market-based approaches and the use of economic incentives for improving water quality and consequently reducing pollutant loads [17]. The policy acknowledges that the progress made toward restoring and maintaining the chemical, physical, and biological integrity of the country's waters under the CWA has been incomplete and that the WQT has the potential to achieve water quality and environmental benefits greater than would otherwise be achieved under more traditional regulatory approaches, at substantial economic savings [17]. Trading programs allow facilities facing higher pollution control costs to meet their

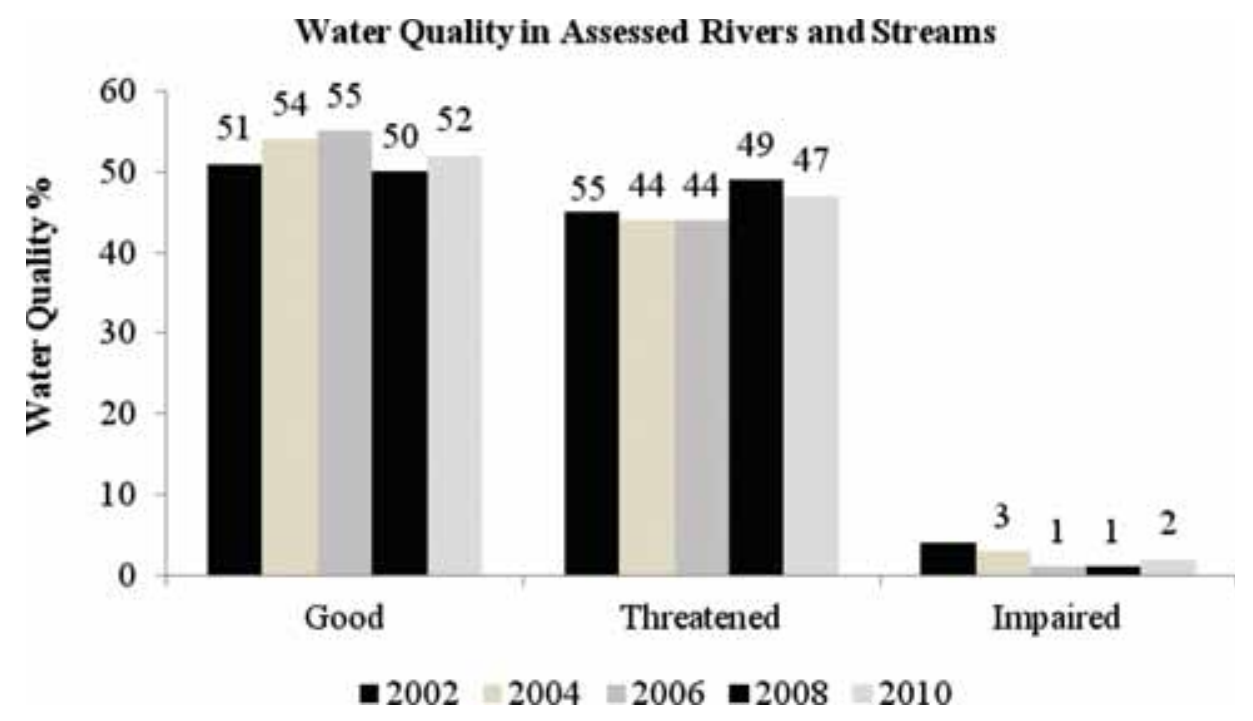

Figure 3: Water quality in assessed rivers and streams for 2002, 2004, 2006, 2008, and 2010. Source: Authors, based on http://www.epa.gov. 
regulatory obligations by purchasing environmentally equivalent (or superior) pollution reductions from another source at lower cost, thus achieving the same water quality improvement at lower overall cost. Where trading involves nonpoint sources, states must adopt methods to account for the greater uncertainty in estimates of nonpoint source loads and reductions.

The WQT is intended to encourage voluntary trading programs that facilitate implementation of TMDLs, reduction in the costs of compliance with CWA regulations, establishment of incentives for voluntary reductions and promotion of watershed-based initiatives [18]. It supports trading to improve or preserve water quality in a variety of circumstances [18]. For example, in unimpaired waters, trading may be used to preserve good water quality by offsetting new or increased discharge of pollutants. In waters impaired by pollutants, trading may be used to achieve earlier pollutant reductions and progress toward WQS pending the development of a TMDL. In addition, trading may be used to reduce the cost of achieving reductions established by a TMDL. According to the EPA website (accessed in January 2011), 25 states are currently in various stages of developing trading programs.

\section{WATER POLLUTION CONTROL MODELS: BRAZIL AND UNITED STATES}

This paper briefly described the Brazilian and the American water pollution control models in terms of regulations and instruments. Based on what was presented in the previous sections, Table 2 summarizes the main findings by making a comparison between the Brazilian and American models.

Table 2: Water Pollution Control Models: Brazil and United States.

\begin{tabular}{|c|c|c|}
\hline & Brazil & USA \\
\hline Water Resources Law & Law 9,433/1997 & Clean Water Act (CWA) \\
\hline Water Quality Regulation & CONAMA 357/2005 & CWA, CFR-Title 40 \\
\hline Effluent Discharge Regulation & CONAMA 411/2011 & CWA, CFR-Title 40 \\
\hline Governmental Institution & ANA & EPA \\
\hline Model & Rigid control system & Flexible control system \\
\hline WQS & $\begin{array}{l}\text { Standards set according to } \\
\text { water body uses }\end{array}$ & $\begin{array}{l}\text { Standards set according to the } \\
\text { water body use }\end{array}$ \\
\hline Effluent discharge limits & Fixed limits & $\begin{array}{l}\text { Flexible limits, according to } \\
\text { the industrial typology. }\end{array}$ \\
\hline Discharge control instrument & Water permits & NPDES \\
\hline $\begin{array}{l}\text { Elements of water quality } \\
\text { management programs }\end{array}$ & $\begin{array}{l}\text { Standard setting, monitoring, } \\
\text { permits issuance, and } \\
\text { enforcement }\end{array}$ & $\begin{array}{l}\text { Standard setting, monitoring, } \\
\text { permits issuance and } \\
\text { enforcement }\end{array}$ \\
\hline $\begin{array}{l}\text { Instrument that integrates effluent } \\
\text { discharges on water bodies, } \\
\text { water quality and the water body } \\
\text { designated uses }\end{array}$ & - & TMDL \\
\hline Market-based instrument & - & WQT Policy \\
\hline Water quality monitoring & ANA & EPA \\
\hline Water quality database & ANA website/ reports & ATTAINS \\
\hline
\end{tabular}

Source: Author. 
As Table 2 indicates, WQS in Brazil in comparison to the United Sates are mandatory set by CONAMA Resolution 357/2005 according to the water body uses. This rule defined fixed WQS for a list of contaminants and substances. Regarding effluent discharges in water bodies, CONAMA Resolution 430/2011 established fixed limits for pollutant discharges in water bodies, demonstrating a rigid control system, where limits do not vary by type of industrial activity.

By analyzing the Brazilian model in comparison to the US model, this study found that Brazil has a more rigid water pollution control system in comparison to the United States, where limits on effluent discharge are set by categories of industrial facilities, whose technological standards are drafted based on the level of reduction that can be attained by each category of industry, through the use of specific technologies defined by the environmental agency. The results of this study also indicates that in the Brazilian water regulation there is no such instrument as the TMDLs, which aims to integrate effluent discharges on water bodies, water quality, and the water body designated use, allowing WQS to be met and thus meet water bodies designated uses. Another important instrument, that is worth to be considered is the WQT, which enables the adoption of market-based approaches and the use of economic incentives for improving water quality and consequently reducing pollutant loads more efficiently and at lower cost. The TMDL can be considered a driver to the WQT policy as it requires facilities to seek pollutant reductions.

\section{CONCLUSIONS}

The analysis of the water quality and effluent discharge regulation in Brazil in comparison with those in the United States shows that Brazil has a rigid control system, where the standards do not vary by type of industry/activity. This rigid control system has evolved with the enactment of Resolution CONAMA 430/2011, but even so, some relevant aspects were not being considered, such as the definition of effluent discharge limits based on industrial activity rather than fixed standards and the inexistence of instruments such as the TMDL and the WQT. This inflexibility engenders an overvaluation of the command and control instrument by the various stakeholders, in detriment to a balanced and integrated view of environmental management. Besides being less effective in protecting the environment, this process imposes huge costs on the different public and private agents.

Therefore, in light of the American water pollution control model and in what has been accomplished so far in Brazil, there are improvements that could be incorporated by Brazilian regulations and also by the Brazilian federal and state institutions. Some categories deserve special mention:

- Promotion of effective decentralization of water resource management, as it occurs in the United States. As mentioned, in the United States, water resource management is guided by a policy of federal-state partnership, where the federal government establishes the agenda and limits while the states are tasked with implementing and overseeing enforcement of the legal determinations.

- Establishment of changes in the definition itself of the effluent discharge conditions, which should be set by categories of industrial facilities, being the technological standards drafted based on the level of reduction that can be attained by each category of industry, through the use of specific technologies defined by the environmental agency.

- Introduction in Brazilian water legislation of an instrument such as the TMDLs, which can integrate effluent discharges on water bodies, water quality, and the water body designated uses, allowing WQS to be met and also address uncontrolled sources of water impairment.

- Introduction in Brazilian legislation an instrument such as the WQT, which in the same way as in the United States would enable the adoption of market-based approaches and the use of economic incentives for improving water quality and consequently reducing pollutant loads. 
- Increase in knowledge about water quality in Brazil, to reduce geographic and temporal gaps in monitoring.

- Standardization of procedures for the collection, frequency of collection, and analysis of water samples so that the data obtained can be comparable on statewide and nationwide levels.

- Achievement of greater articulation between the ANA and stage agencies.

\section{ACKNOWLEDGMENTS}

The authors thank Coordenação de Aperfeiçoamento de Pessoal de Nível Superior (CAPES) and Fundação de Amparo a Pesquisa no Estado do Rio de Janeiro (FAPERJ) and for the post doctoral grant, making possible the development of this study.

\section{REFERENCES}

[1] Magrini, A. \& Santos, M., River Basin Management and the National Water Resources Policy in Brazil, eds. C.A. Brebbia, P. Anagnostopoulos, K. Katsifarakis \& A.H-D. Cheng, (Org.). Water Resources Management: Southampton, v. 4, pp. 79-88, 2001.

[2] Elabras-Veiga, L.B. \& Magrini, A., Water Resources Management: Suggestions to the Brazilian Model Based on the American Experience, eds: C.A. Brebia \& V. Popov. (Org.). Water Resources Management VI. 01 ed. WIT Press: United Kingdon, v. VI, pp. 39-50, 2011.

[3] Guimarães, L. \& Magrini, A., A proposal of indicators for sustainable development in the management of river basins. Water Resource Management, 22, pp. 1191-1202, December 2007. doi: http://dx.doi.org/10.1007/s11269-007-9220-x

[4] Elabras-Veiga, L. B., Dez anos da Lei $n^{o} .9 .433$ de 1997: atual estágio de implementação e comparação com a Legislação Internacional de Gestão de Recursos Hídricos, Relatório de Pesquisa, Fundação de Amparo a Pesquisa no Estado do Rio de Janeiro - FAPERJ, RJ, Brasil, Setembro 2010.

[5] Instituto Brasileiro de Geografia e Estatística (IBGE), available at http://www.ibge.org.br

[6] Agência Nacional de Águas (ANA), Conjuntura dos Recursos Hídricos no Brasil, ANA, Brasília, 2009.

[7] Agência Nacional de Águas (ANA), Conjuntura dos Recursos Hídricos no Brasil, Brasília, 2011.

[8] Magrini, A., Szklo, A.S., Elabras-Veiga, L.B., Henriques, R. \& Silva, R.G., A cross-sectional analysis of Brazil's effluent discharge regulation. In: Fourth International Conference on River Basin Management Including all aspects of Hydrology, Ecology, Environmental Management, Flood Plains and Wetlands, 2007, KOS, Greece.

[9] Copeland, C., Clean Water Act: a summary of the Law, CSR Report for Congress 30030, USA, August 2008.

[10] Salzman, J. \& Thompson Jr., B.H., Environmental law and policy (Chapter 5). Water Pollution, Foundation Press: USA, pp. 137-164, 2007.

[11] United States Environmental Protection Agency (US-EPA), National Recommended Water Quality Criteria, Washington, D.C., 2006, available at www.epa.org

[12] United States Environmental Protection Agency (US-EPA), Water Quality Standards Handbook - 2nd edn, Washington, D.C., 1994.

[13] United States Environmental Protection Agency (US-EPA), Technical Support Document for Effluent Guidelines Program Plan, Washington, D.C., 2004.

[14] United States Environmental Protection Agency (US-EPA), Protecting the Nations' Waters Through Effective NPDES Permit, A Strategic Plan for 2001 and beyond, Washington, 2001. 
[15] Copeland, C., Clean Water Act and Total Maximum Daily Loads (TMDLs) of Pollutants, CSR Report for Congress 97-831, USA, 2008.

[16] United States Environmental Protection Agency (US-EPA), NPDES Permit: Writers Manual, US-EPA, Washington, D.C., 1996.

[17] US-EPA, United States Environmental Protection Agency, "Water Quality Trading Assessment Handbook: Can Water Quality Trading Advance Your Watershed's Goals?”, Washington, D.C., 2004, available at www.epa.org

[18] US-EPA, United States Environmental Protection Agency, "Water Quality Trading Evaluation, Final Report: Through Evaluation Promoting Environmental Results", Washington, D.C., 2008, available at www.epa.org 